\title{
Keanekaragaman, Bioekologi Ikan di Perairan Pantai Barat Pulau Rempang Kecamatan Galang Kota Batam
}

\section{The Diversity and Bioecology of Fishes In West Waters of Rempang Islands, Galang Prefecture Batam City}

\author{
Notowinarto $^{1}$ dan Lani Puspita ${ }^{2}$ \\ ${ }^{12}$ Program Pendidikan Biologi, Fakultas Keguruan dan Ilmu Pendidikan, \\ Universitas Riau Kepulauan, Indonesia \\ Koresponden: notowinarto@yahoo.co.id
}

\begin{abstract}
Abstrak
Penelitian ini dilaksanakan selama 5 bulan, dimulai bulan Juni hingga Oktober 2019, yang berlokasi di area perairan tangkap pantai Barat P. Rempang. Lokasi pengamatan terdiri dari 3 stasiun antara lain: P. Nibung (St. 1); P. Panjang Dalam (St. II); P. Panjang Luar (St. III). Tujuan penelitian ini untuk mengetahui keanekaragaman ikan, karakteristik taksonomi spesies ikan dan kondisi bioekologi ikan. Hasil identifikasi diperoleh bahwa ikan di perairan pantai Barat P. Rempang tergolong ke dalam 3 ordo, 18 famili, dan 29 spesies dengan 10 jenis ikan yang dominan yakni: Bandeng, Belanak, Dingkis, Gelam, Kurisi ekor kuning, Kurisi merah, Lingkis, Lebam, Mentimun tande dan Mentimun garis kuning. Kondisi kualitas fisika-kimia perairan parameter suhu, salinitas, DO, pH, kecepatan arus, dan kecerahan relatif normal. Analisis status ekobiologi memperlihatkan 10 spesies cenderung bernilai kecil yakni rata-rata $<1$ atau berkisar $0,005-0,215$ yang berarti bahwa pola pertumbuhan adalah allometrik (negatif) dimana pertumbuhan panjang lebih cepat dari pertumbuhan bobot tubuh. Tinjauan faktor kondisi Fulton (K) memperlihatkan kisaran nilai 17,60 - 30,46. Faktor kondisi berat relatif $(\mathrm{Wr})$ tertinggi terdapat pada ikan belanak $(107,81)$ dan terendah pada ikan bandeng $(103,13)$, dimana kedua jenis ikan ini masih pada rentang nilai yang berdekatan dengan nilai indikator 100 yang berarti bahwa terdapat keseimbangan antara mangsa dan predator.
\end{abstract}

Kata Kunci: Keanekaragaman, Taksonomis dan Bioekologi Ikan

\begin{abstract}
This research was conducted for 5 months, starting from June to October 2019, which is located in the catchment area of the West coast of Rempang Island. The observation site consisted of 3 stations including P. Nibung (St. 1); P. Panjang Dalam (St. II); P. Outer Length (St. III). The study wasaim is to determine fish diversity, taxonomic characteristics of fish species and fish bioecological conditions. The identification results obtained that the fish in the waters of the West coast P. Rempang classified into 3 orders, 18 families, and 29 species with 10 species of dominant fish namely: Milkfish, Belanak, Dingkis, Gelam, Yellow tail Kurisi, Red Kurisi, Lingkis, Lebam, Tande cucumber and yellow line cucumber. The physical-chemical quality conditions of the water parameters are temperature, salinity, $D O, p H$, current speed, and brightness are relatively normal. The ecological status analysis shows that 10 species tend to be of little value, that is, average $<1$ or around $0.005-0.215$, which means that the growth pattern is allometric (negative) where long growth is faster than body weight growth. A review of the Fulton $(K)$ condition factor shows the range of values $17.60-30.46$. The highest relative weight condition (Wr) is found in mullet fish (107.81) and the lowest in milkfish (103.13), where both of these fish species are still in the range of values close to the indicator value 100 which means that there is a balance between prey and predators.
\end{abstract}

Keywords: Diversity, Taxonomy and Ecobiological. 


\section{PENDAHULUAN}

Beberapa faktor yang berhubungan langsung terhadap populasi ikan dalam suatu perairan antara lain adalah jumlah dan kualitas makanan yang tersedia, ketersediaan makanan dan durasi waktu pengambilan makanan oleh ikan dalam populasi tertentu (Yuniar, 2017). Makanan tersebut akan mempengaruhi pertumbuhan, serta kelangsungan hidup (survival). Ketersediaan makanan dalam perairan juga ditentukan oleh kondisi abiotik lingkungan seperti suhu, cahaya, ruang, dan luas permukaan.

Hubungan morfometrik antara panjang dan berat ikan merupakan indeks untuk mengetahui aspek biologi ikan, seperti pertumbuhan, kematangan gonad, reproduksi, dan kesehatan ikan. Data panjang dan berat ikan umumnya digunakan untuk memperoleh informasi status dan populasi keanekaragaman taksonomi jenis ikan di habitat tersebut. Hal ini diperlukan untuk mengatur tingkat eksploitasi dalam melakukan pengelolaan terhadap populasi jenis ikan tertentu. Kondisi variasi pertumbuhan ikan berdasarkan musim juga dapat diperkirakan dengan melihat hubungan panjang-berat. Hubungan panjang-berat ikan merupakan salah satu informasi pelengkap dalam pengelolaan sumber daya perikanan, misalnya dalam selektifitas alat tangkap agar ikan-ikan yang tertangkap hanya ikan yang berukuran layak tangkap (Vanichkul \& Hongskul dalam Mulfizar, et al., 2012). Hubungan panjang-berat juga berguna untuk mengetahui faktor kondisi populasi terkait hasil tangkapan dan pola pertumbuhan ikan (Muttaqin, et, al., 2016).

Pertumbuhan mutlak pada umumnya ditandai dengan terjadinya perubahan bobot ataupun panjang dalam kurun waktu 1 (satu) tahun. Sedangkan pertumbuhan nisbi merupakan selisih persentase pertumbuhan pada tiap interval waktu atau perbedaan ukuran pada waktu akhir interval dibagi waktu awal interval (Arifiantri, 2006). Pada ikan terdapat perubahan terus-menerus secara proposional dalam tubuhnya yang dikenal dengan pertumbuhan isometrik atau isogenik (Effendie, 2002). Pada umumnya terdapat perbedaan pertumbuhan ikan jantan dengan betina. Pada ikan Nomai, pertumbuhan betina relatif lebih lambat dibandingkan pertumbuhan ikan jantan (Firdaus, et al., 2013).

Penelitian tentang identifikasi keanekaragaman dan bioekologi ikan di perairan pantai Barat Kota Batam belum pernah dilaporkan. Oleh karena itu penelitian yang terkait tentang morfometrik, hubungan panjang berat, pola pertumbuhan dan faktor kondisi ikan di perairan Barat Pulau Rempang Kota Batam penting untuk dilakukan. 


\section{METODOLOGI PENELITIAN}

Penelitian ini dilaksanakan selama 5 (lima) bulan dari Juni hingga Oktober 2019. Lokasi penelitian berada di kawasan perairan Barat Pulau Rempang, Kecamatan Galang Kota Batam. Pengamatan dilakukan di 3 stasiun antara lain; perairan P. Nibung (St. I), P. Panjang Dalam (St. II), dan P. Panjang Luar (St. III). Pengambilan sampel dilakukan secara purposive sampling dengan satu hingga dua kali ulangan pada setiap stasiun pengamatan.

Tabel 1. Koordinat Stasiun Penelitian

\begin{tabular}{llcc}
\hline Stasiun. & Nama Stasiun & Lintang Utara & Bujur Timur \\
\hline I. & Pulau Nibung & $0^{0} 51^{\prime} 10^{\prime \prime}$ & $104^{0} 8,55^{\prime}$ \\
II. & P. Panjang Dalam & $0^{0} 48^{\prime} 20^{\prime \prime}$ & $104^{0} 99^{\prime} 195^{\prime}$ \\
III. & P. Panjang Luar & $0^{0} 46^{\prime} 43^{\prime \prime}$ & $104^{0} 8,30^{\prime \prime}$ \\
\hline
\end{tabular}

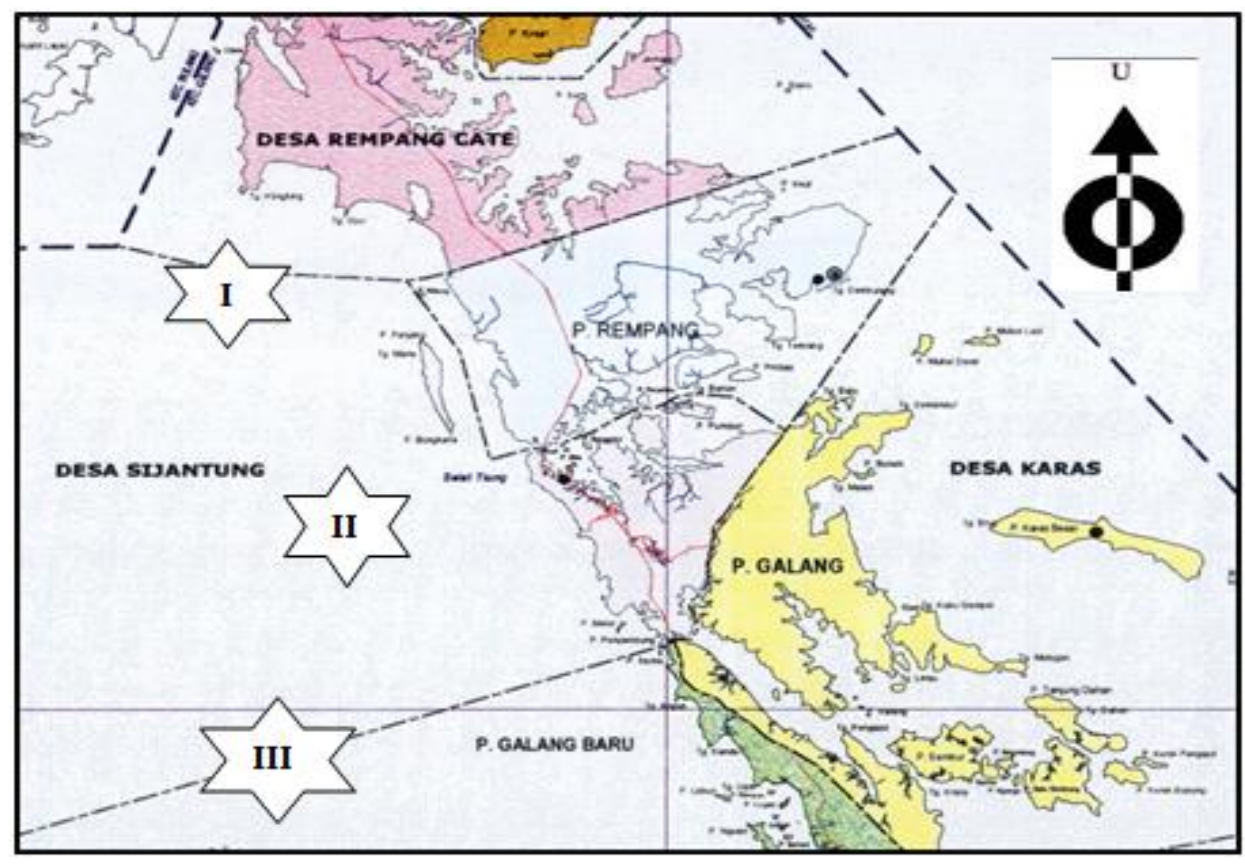

Gambar 1. Stasiun Pengambilan Sampel

Sampel ikan diperoleh berdasarkan hasil tangkapan menggunakan alat tangkap jaring insang ukuran mata jaring 2,5 inchidengan lebar 2,5 m dan panjang $250 \mathrm{~m}$. Selanjutnya ikan sampel dimasukkan ke dalam cool box kemudian dibawa ke Laboratorium untuk diidentifikasi dan di analisis lebih lanjut. Analisis morfometrik dan identifikasi ikan merujuk Min, et. al., 1982. Parameter pengukuran morfometrik ikan secara rinci dapat dilihat pada Gambar 2.

Pengukuran kualitas fisika-kimia perairan dilakukan secara in situ yang meliputi parameter kecerahan, salinitas, oksigen terlarut, $\mathrm{pH}$, kecepatan arus, dan suhu. Analisis data meliputi: 1). Analisis panjang berat menggunakan Model Allometric Linear (LAM) 
(Muchlisin, et al., 2010; Rahardjo, 2011; Ramadhani, et al., 2017); 2). Analisis faktor kondisi setiap individu ikan menggunakan persamaan Rypel dan Richter (2008) dan faktor kondisi Fulton dihitung berdasarkan Muchlisin et al., (2010); Usman \& Affandi. (2017).

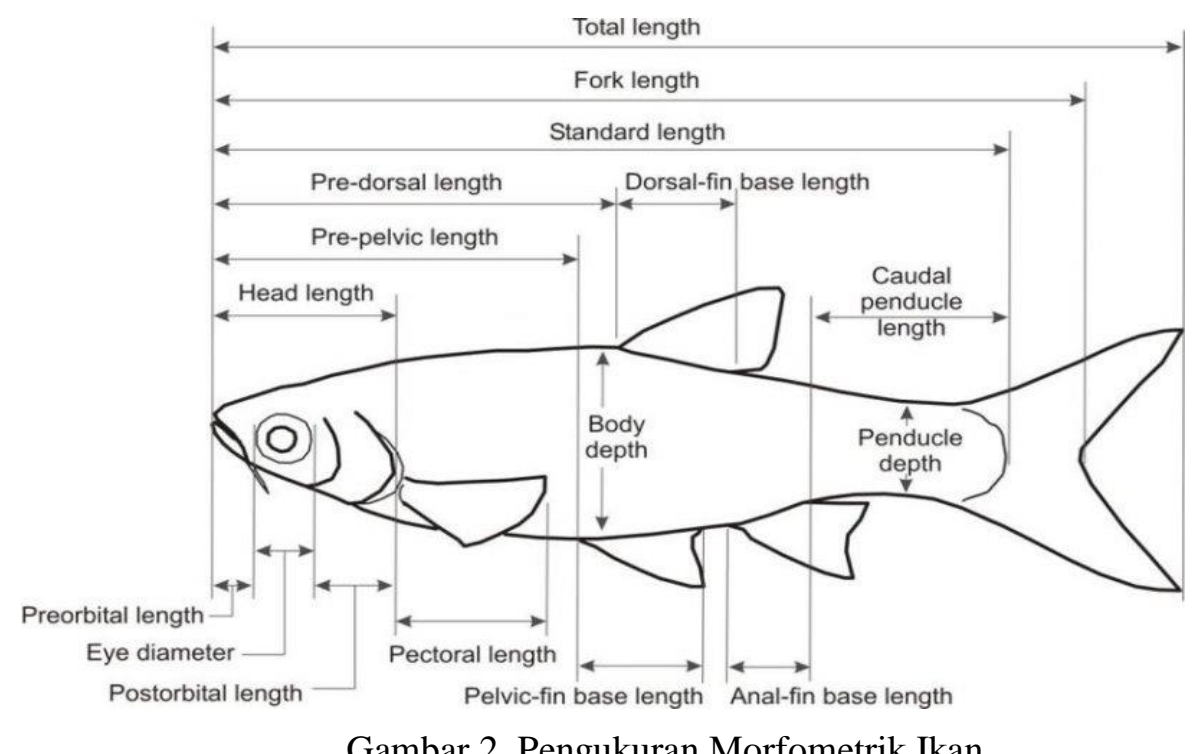

Gambar 2 Pengukuran Morfometrik Ikan

\section{HASIL DAN PEMBAHASAN}

Hasil inventarisasi dan identifikasi spesimen ikan secara tasonomi diperoleh 29 Spesies, 18 Familia dan 3 Ordo, dimana 10 jenis diantaranya merupakan ikan hasil tangkapan yang dominan (Tabel 2). Hasil identifikasi terhadap hasil tangkapan berdasarkan bulan selama penelitian berlangsung sebagai berikut: bulan Juni 13 spesies; Juli 14 spesies; Agustus 18 spesies; September 15 spesies dan Oktober 11 spesies dengan frekuensi kehadiran jenis ikan yang dominan antara lain: Bandeng, Belanak, Dingkis, Gelam, Kurisi ekor kuning, Kurisi merah, Lingkis, Lebam, Mentimun tande dan Mentimun garis kuning (Tabel 3).

Pengkategorian berdasarkan takson kekerabatan ordo didapati bahwa ordo Perciformes mendominasi dengan 27 familia, ordo Gonorynchiformes dan ordo Balastiformes masingmasing hanya 1 familia. Jika ditelaah lebih lanjut berdasarkan takson familia terhadap jumlah hasil sampling yang tertangkap, maka kelompok familia Siganidae dengan 3 spesies berjumlah 195 ekor, diikuti familia Mugilidae dengan 1 spesies berjumlah 120 ekor, familia Lutjanidae, 4 spesies berjumlah 112, familia centropomidae, 1 spesies sebanyak 79 ekor dan familia Elopsidae, 1 spesies sebanyak 24 ekor (Tabel 4). 
Tabel 2. Inventarisasi Keanekaragaman Jenis Ikan Hasil Tangkapan Jaring Insang Periode Juni hingga Oktober 2019

\begin{tabular}{|c|c|c|c|c|}
\hline No. & $\begin{array}{l}\text { Nama Lokal } \\
\text { Spesies Ikan }\end{array}$ & Genus/Spesies & Familia & Ordo \\
\hline 1 & Alu-alu & Thylosurus spp & Belenidae & Perciformes \\
\hline 2 & Bandeng Buri & Chanos chanos & Chanidae & Gonorynchiformes \\
\hline 3 & Bawal Putih & Pampus sp & Ephippidae & Perciformes \\
\hline 4 & Biji Nangka & Upeneus sp & Mullidae & Perciformes \\
\hline 5 & Belanak Putih/Bakau//Ciot & Valamugil seheli & Mugillidae & Perciformes \\
\hline 6 & Buna/Domol & Platax batavianus & Ephippidae & Perciformes \\
\hline 7 & Dingkis & Siganus guttatus & Siganidae & Perciformes \\
\hline 8 & Gelam/Jelam/Kakap Putih & Lates calcarifes & Centropomidae & Perciformes \\
\hline 9 & Kacang-kacangan (putih) & Sphyraena langsar & Belenidae & Perciformes \\
\hline 10 & Kaci & Plectorhynchus pichtus & Pomodasyidae & Perciformes \\
\hline 11 & Kapasan & Gerres filamentous & Gerridae & Perciformes \\
\hline 12 & Kitang & Drepane puctata & Drepanidae & Perciformes \\
\hline 13 & Kurisi ekor kuning/mensire & Nemipterus tambiuloides & Nemipteridae & Perciformes \\
\hline 14 & Kurisi Merah & Nemipterus bleekeri & Nemipteridae & Perciformes \\
\hline 15 & Kurau & Eleutherone sp & Polynemidae & Percesoces \\
\hline 16 & Kerapu Lumpur & Epinephelus sp & Serranidae & Perciformes \\
\hline 17 & Kerapu Sunu & Plectropomus aerolatus & Serranidae & Perciformes \\
\hline 18 & Kerapu Merah & Plectropomus sp & Serranidae & Perciformes \\
\hline 19 & Kerosok/Mengkosok & Monocanthus chinensis & Balastidae & Tetraodontiformes \\
\hline 20 & Ketarap/Tokak/Mencok & Scarus chamaleon & Scaridae & Perciformes \\
\hline 21 & Lingkis & Siganus canaliculatus & Siganidae & Perciformes \\
\hline 22 & Lebam/Gelibas & Siganus javus & Siganidae & Perciformes \\
\hline 23 & Mentimun tande (hitam) & Lutjanus monostigma & Lutjanidae & Perciformes \\
\hline 24 & Mentimun Garis2 Kuning & Lutjanus kasmira & Lutjanidae & Perciformes \\
\hline 25 & Mempinang & Lutjanus lentjan & Lutjanidae & Perciformes \\
\hline 26 & Mentimah/Palete & Alepes kalla & Lutjanidae & Perciformes \\
\hline 27 & Mengkerong & Pelates quadrilinieatus & Lutjanidae & Perciformes \\
\hline 28 & Rombeng & Abudefduf septemfasciatus & Pomacentridae & Perciformes \\
\hline 29 & Talang Seliap & Chorinemus commersonianus & Carangidae & Perciformes \\
\hline
\end{tabular}

Tabel 3. Rekapitulasi Jumlah Jenis Ikan yang Mendominasi Hasil Tangkapan Jaring Insang Periode Juni hingga Oktober 2019 (frekwensi/jumlah/ekor/bulan)

\begin{tabular}{clcccccc}
\hline \multirow{2}{*}{ No. Jenis Ikan } & \multicolumn{6}{c}{ Jumlah Ikan Sampling (ekor) } & Jumlah \\
\cline { 3 - 8 } & & Jun & Jul & Ags & Sept & Okt & \\
\hline 1 & Bandeng Buri & 5 & 7 & - & 12 & - & 24 \\
2 & Belanak Putih /Ciot /Bakau/ & 32 & 67 & 8 & 6 & 7 & 120 \\
3 & Dingkis & - & 3 & 43 & - & - & 46 \\
4 & Gelam/Jelam/Kakap Putih & 13 & 11 & 37 & 9 & 9 & 79 \\
5 & Kurisi ekor kuning/mensire & 3 & 6 & 10 & 8 & - & 27 \\
6 & Kurisi Merah & 2 & - & 29 & 3 & - & 34 \\
7 & Lingkis & 4 & 12 & 97 & 14 & 7 & 134 \\
8 & Lebam/Gelibas & 10 & - & 5 & - & - & 15 \\
9 & Mentimun Tande & 4 & 2 & - & 3 & 2 & 11 \\
10 & Mentimun Garis2 Kuning & 5 & 6 & 26 & - & 3 & 40 \\
\hline
\end{tabular}


SIMBIOSA Vol 8 (2): 188-197, Desember 2019

DOI: 10.33373/sim-bio.v8i2.2182

Notowinarto \& Lani Puspita, 2019. The Diversity and Bioecology of Fishes

Terjadinya perbedaan hasil tangkapan diduga dipengaruhi oleh kondisi musim. Periode Juni hingga Agustus merupakan rentang bulan yang mewakili kondisi musim panas, sedangkan memasuki pertengahan bulan September hingga Oktober mewakili rentang waktu musim hujan.

Tabel 4. Jumlah Jenis Ikan yang Mendominasi Berdasarkan Kekerabatan Familia dari Hasil Tangkapan Jaring Insang Periode Juni hingga Oktober 2019

\begin{tabular}{|c|c|c|c|c|c|c|c|}
\hline \multirow[b]{2}{*}{ No. } & \multirow[b]{2}{*}{ Jenis Ikan } & \multicolumn{6}{|c|}{ Jumlah Ikan Tangkapan } \\
\hline & & Jun & Jul & Ags & Sept & Okt & $\begin{array}{c}\text { Jumlah } \\
\text { (ekor) }\end{array}$ \\
\hline \multirow[t]{2}{*}{1} & Centropomidae & & & & & & \\
\hline & Gelam/Jelam/Kakap Putih & 13 & 11 & 37 & 9 & 9 & 79 \\
\hline \multirow[t]{2}{*}{2} & Elopsidae & & & & & & \\
\hline & Bandeng Buri & 5 & 7 & - & 12 & - & 24 \\
\hline \multirow[t]{5}{*}{3} & Lutjanidae & & & & & & \\
\hline & Kurisi ekor kuning/mensire & 3 & 6 & 10 & 8 & - & 27 \\
\hline & Kurisi Merah & 2 & - & 29 & 3 & - & 34 \\
\hline & Mentimun Tande & 4 & 2 & & 3 & 2 & 11 \\
\hline & Mentimun Garis2 Kuning & 5 & 6 & 26 & - & 3 & 40 \\
\hline \multirow[t]{2}{*}{4} & Mugillidae & & & & & & \\
\hline & Belanak Putih /Ciot/Bakau/ Rampang & 32 & 67 & 8 & 6 & 7 & 120 \\
\hline \multirow[t]{4}{*}{5} & Siganidae & & & & & & \\
\hline & Dingkis & - & 3 & 43 & - & - & 46 \\
\hline & Lingkis & 4 & 12 & 97 & 14 & 7 & 134 \\
\hline & Lebam/Gelibas & 10 & - & 5 & - & - & 15 \\
\hline
\end{tabular}

Perubahan musim yang terjadi akan mempengaruhi kondisi kualitas perairan seperti suhu, salinitas, DO, pH, kecepatan arus, dan kecerahan. Meskipun musim dapat mempengaruhi kondisi kualitas perairan, namun pada penelitian ini kondisi kualitas perairan relatif normal. Kondisi ini dapat berarti bahwa faktor lingkungan perairan yang normal akan mampu mempertahankan keanekaragaman jenis ikan, meskipun keanekaragaman jenis ikan tersebut baik secara langsung maupun tidak langsung akan dipengaruhi oleh perubahan musim.

Tabel 5 Nilai Parameter Fisik-Kimia Perairan Pada Bulan Juni dan Oktober 2019

\begin{tabular}{clcccccc}
\hline \multirow{2}{*}{ No } & Parameter Fisik dan Kimia & \multicolumn{5}{c}{ Waktu dan Stasiun Pengamatan } \\
\cline { 3 - 8 } & Perairan & \multicolumn{4}{c}{ Akhir Jun* } & \multicolumn{4}{c}{ Akhir Oktober** } \\
\cline { 2 - 7 } & & St I & St II & St III & St I & St II & St III \\
\hline 1 & Suhu $\left({ }^{\circ} \mathrm{C}\right)$ & 32,2 & 32,0 & 31,9 & 30,9 & 29,7 & 31,2 \\
2 & Larutan Oksigen (Mg/l) & 29,4 & 32,0 & 31,9 & 31,9 & 31,7 & 31,8 \\
3 & pH & 8,0 & 8,0 & 8,0 & 8,1 & 8,1 & 8,3 \\
4 & Salinitas (\%o) & 34,3 & 34,7 & 35 & 30,3 & 33,7 & 34,3 \\
5 & Kecepatan Arus (Detik) & 37,0 & 31,0 & 30,7 & 50,7 & 33,7 & 46,1 \\
6 & Kecerahan (M) & 1,2 & 1,8 & 1,5 & 2,5 & 3,6 & 3,0 \\
\hline *Musim panas ; **Musim Hujan & & & & & &
\end{tabular}


Analisis terhadap karakter pertumbuhan beberapa jenis ikan dominan terhadap kondisi status ekobiologi pertumbuhan menggunakan analisis morfometrik hubungan panjang berat berdasarkan katagori kekerabatan familia dapat dilihat pada Tabel 6. Kondisi bioekologi dari status hubungan pertumbuhan panjang berat ikan, terdapat kecenderungan bahwa 10 spesies dianggap dominan dengan nilai yang sangat kecil yakni rata-rata $<1$ atau berkisar 0,005 0,215. Hal ini berarti bahwa pola pertumbuhan adalah allometrik negatif dimana pertumbuhan panjang lebih cepat dari pertumbuhan bobot tubuh.

Pada umumnya karakter ini dijumpai pada ikan golongan pelagis kecil yang selalu melakukan migrasi lokal dan secara temporal golongan ikan pelagis besar. Lokasi perairan diduga merupakan tempat bermain mencari makan (fishing-feeding area) dan bukan lokasi pemijahan dan dareah asuhan (breeding-nursery ground).

Tabel 6 Hasil Analisis Regresi Terhadap Pertumbuhan Jenis Ikan Berdasarkan Dominasi dan Kekerabatan Familia serta berdasarkan Katagori Familia.

\begin{tabular}{|c|c|c|c|c|c|c|}
\hline No. & Spesies & $\begin{array}{c}\text { Koefisien } \\
\text { Determinan } \\
\left(\mathbf{R}^{2}\right)\end{array}$ & $\begin{array}{c}\text { Koefisien } \\
\text { Korelasi } \\
(\mathbf{r}) \\
\end{array}$ & $\begin{array}{c}\text { Nilai } \\
\text { Eksponen } \\
\text { 'b' }\end{array}$ & $\mathbf{W}=\mathbf{a} \mathbf{L}^{\mathbf{b}}$ & $\begin{array}{c}\text { Pola } \\
\text { Pertumbuhan }\end{array}$ \\
\hline $\mathbf{A}$ & \multicolumn{6}{|c|}{ Berdasarkan Jenis Ikan yang Dominan } \\
\hline 1. & Bandeng Buri (Elops $s p$ ) & 0,972 & 0,985 & 0,009 & $\mathrm{~W}=0,319 \mathrm{~L}^{0,009}$ & Alometrik (-) \\
\hline 2. & $\begin{array}{l}\text { Belanak Putih /Ciot } \\
\text { (Valamungil sp) }\end{array}$ & 0,711 & 0,843 & 0,019 & $\mathrm{~W}=0,128 \mathrm{~L}^{0,019}$ & Alometrik (-) \\
\hline 3. & $\begin{array}{l}\text { Gelam/Jelam/Kakap Putih } \\
(\text { Lates sp) }\end{array}$ & 0,864 & 0,929 & 0,139 & $\mathrm{~W}=0,181 \mathrm{~L}^{0,139}$ & Alometrik (-) \\
\hline 4. & $\begin{array}{l}\text { Kurisi ekor kuning/ Mensire } \\
\text { (Nemipterus } s p \text { ) }\end{array}$ & 0,866 & 0,930 & 0,089 & $\mathrm{~W}=0,173 \mathrm{~L}^{0,089}$ & Alometrik (-) \\
\hline 5. & Kurisi Merah & 0,159 & 0,398 & 0,005 & $\mathrm{~W}=0,158 \mathrm{~L}^{0,005}$ & Alometrik (-) \\
\hline 6. & Lingkis (S canaliculatus) & 0,999 & 0,999 & 0,102 & $\mathrm{~W}=0,222 \mathrm{~L}^{0,102}$ & Alometrik (-) \\
\hline 7. & Mentimun Tande (Lutjanus sp) & 0,249 & 0,498 & 0,215 & $\mathrm{~W}=0,295 \mathrm{~L}^{0,215}$ & Alometrik (-) \\
\hline 8. & Mentimun Garis Kuning & 0,244 & 0,497 & 0,043 & $\mathrm{~W}=0,229 \mathrm{~L}^{0,043}$ & Alometrik (-) \\
\hline $\mathbf{B}$ & \multicolumn{6}{|c|}{ Berdasarkan Katagori Kekerabatan Familia } \\
\hline 1. & Mugillidae & 0,711 & 0,843 & 0,019 & $\mathrm{~W}=0,128 \mathrm{~L}^{0,019}$ & Alometrik (-) \\
\hline 2. & Centropomidae & 0,864 & 0,929 & 0,139 & $\mathrm{~W}=0,181 \mathrm{~L}^{0,139}$ & Alometrik (-) \\
\hline 3. & Siganidae & 0,823 & 0,907 & 0,295 & $\mathrm{~W}=0,319 \mathrm{~L}^{0,295}$ & Alometrik (-) \\
\hline 4. & Lutjanidae & 0,781 & 0,884 & 0,216 & $\mathrm{~W}=0,381 \mathrm{~L}^{0,216}$ & Alometrik (-) \\
\hline
\end{tabular}

Hasil analisis faktor kondisi pertumbuhan Fulton (K) dari beberapa jenis ikan diperoleh nilai indeks yang menunjukkan kondisi kesehatan ikanyang cenderung mendekati nilai 100 . Berdasarkan nilai tersebut, maka faktor kondisi masih berada dalam kategori sangat baik serta menunjukkan keseimbangan rantai makanan di lingkungan perairan tersebut (Tabel 7).

Tinjauan hasil analisis Faktor Kondisi Fulton (K) dan Faktor Kondisi Berat Relatif (Wr) 
SIMBIOSA Vol 8 (2): 188-197, Desember 2019

DOI: 10.33373/sim-bio.v8i2.2182

Notowinarto \& Lani Puspita, 2019. The Diversity and Bioecology of Fishes

sebagai berikut: ikan Belanak memiliki nilai tertinggi $(107,81)$ dan terendah ikan Bandeng $(103,13)$, kedua jenis ikan ini maupun ikan lainnya masih dalam kisaran rentang yang berdekatan dengan nilai indikator 100. Hal ini berarti bahwa faktor kondisi masih berada dalam kondisi sangat baik dimana kondisi rantai makanan antara mangsa dan predator masih dalam kategori seimbang. Effendie dalam Gazali \& Firdaus (2011), menyatakan bahwa jika nilai indeks $\mathrm{K}$ berkisar antara 1-3, maka ikan akan memiliki bentuk tubuh pipih.

Tabel 7. Hasil Analisis Faktor Kondisi Fulton (K) dan Faktor Kondisi Berat Relatif (Wr) Berdasarkan Dominasi dan Kekerabatan Familia

\begin{tabular}{clcc}
\hline No. & Jenis Ikan & $\begin{array}{c}\text { Nilai } \\
\text { Faktor K }\end{array}$ & $\begin{array}{c}\text { Nilai } \\
\text { Faktor Wr }\end{array}$ \\
\hline A & Berdasarkan Jenis Ikan yang Dominan & & \\
1. & Bandeng (Elops sp) & 26,13 & 103,13 \\
2. & Belanak Putih /Ciot (Valamungil sp) & 20,73 & 107,81 \\
3. & Gelam/Kakap Putih (Lates sp) & 22,75 & 105,52 \\
4. & Kurisi ekor kuning/Mensire (Nemipterus tambiuloides) & 16,39 & 105,79 \\
5. & Kurisi Merah (Nemipterus bleekeri) & 20,32 & 106,33 \\
6. & Lingkis (Siganus canaliculatus) & 17,60 & 104,51 \\
7. & Mentimun Tande (Lutjanus monostigma) & 30,46 & 103,39 \\
8. & Mentimun GarisKuning (Lutjanus kasmira) & 22,26 & 104,37 \\
\hline B & Berdasarkan Katagori Kekerabatan Familia & & \\
1. & Mugillidae & 11,53 & 107,81 \\
2. & Centropomidae & 22,75 & 105,52 \\
3. & Siganidae & 12,46 & 103,72 \\
4. & Lutjanidae & 11,56 & 102,62 \\
\hline
\end{tabular}

Identifikasi spesimen ikan berdasarkan taksonomi diperoleh 29 Spesies dengan 10 jenis ikan dominan, dimana dari 10 spesies tersebut diketahui nilai pertumbuhan kecil, yakni ratarata $<1$ atau berkisar 0,005-0,215. Hal ini menunjukkan bahwa pola pertumbuhan adalah allometrik negatif dimana pertumbuhan panjang lebih cepat dibandingkan pertumbuhan bobot tubuh. Hasil penelitian keanekaragaman ikan di perairan Barat-Utara Pulau Batam diperoleh ikan yang tergolong ke dalam 6 ordo, 19 famili, dan 28 spesies, dimana ordo pada wilayah perairan barat diketahui lebih banyak di bandingkan pada wilayah lainnya. Indeks Keanekaragaman $\left(\mathrm{H}^{\prime}\right)$ pada seluruh stasiun pengamatan berkisar antara 1,066-1,918 yang berarti bahwa dalam kondisi baik. Rejeki (2013) menyatakan bahwa keanekaragaman jenis ikan pada perairan disekitar vegetasi mangrove jenis Rhizophora sp. diperoleh 10 famili ikan. Hasil ini sangat sedikit bila dibandingkan dengan spesies ikan yang terdapat di lokasi penelitian. 
Ada kecenderungan bahwa padaa kawasan perairan terbuka, ikan yang paling banyak ditemui umumnya dari Famili Mugilidae merupakan jenis ikan yang paling banyak ditemui pada kawasan perairan terbuka karena mampu hidup pada kisaran salinitas yang luas, seperti daerah sekitar pantaidan muara sungai. Ikan dengan Famili Mungilidae biasanya bersifat katadromous, dan paling banyak tertangkap saat fase juvenil. Salah satu contohnya adalah ikan Belanak.

Ikan Belanak hidup berasosiasi dengan hutan mangrove selama periode anakan, tetapi saat dewasa cenderung banyak dijumpai pada perairan pantai. Berdasarkan pengamatan selama penelitian diketahui bahwa kelimpahan ikan saat kondisi surut lebih tinggi dibandingkan pada saat kondisi pasang. Brown dalam Alfiyah, et al., (2016) menyatakan bahwa setiap spesies ikan mempunyai sebaran geografi tertentu yang dikontrol oleh kondisi fisik lingkungannya. Sebaran, populasi dan variasi morfometri yang berbeda merupakan respon terhadap lingkungan fisik dimana spesies tersebut hidup. Variasi keanekaragaman jenis merupakan isolasi reproduksi yang bukan hanya disebabkan oleh perbedaan lingkungan (Usman \& Affandi, 2017).

\section{KESIMPULAN}

Keanekaragaman ikan di perairan pantai Barat Pulau Rempang terdiri dari 3 ordo, 18 famili, dan 29 spesies, dimana terdapat 10 spesies ikan yang paling mendominasi perairan yaitu: Bandeng, Belanak, Dingkis, Gelam, Kurisi ekor kuning, Kurisi merah, Lingkis, Lebam, Mentimun tande dan Mentimun garis kuning.Kondisi ekobiologi dari status hubungan pertumbuhan panjang berat dari 10 spesies ikan menunjukkan pola pertumbuhan allometrik negatif dimana pertumbuhan panjang lebih cepat dari pertumbuhan bobot tubuh. Faktor kondisi Fulton (K) berkisar antara 17,60 - 30,46 dan faktor kondisi Berat Relatif (Wr) sebesar 103,13 untuk ikan Bandeng dan 107,81 untuk ikan Belanak.

\section{UCAPAN TERIMA KASIH}

Mengucapkan terimakasih telah membiayai dan menyelesaikan Penelitian Hibah Internal Universitas Riau Kepulauan (UNRIKA) kepada: Ketua Yayasan Perguruan Tinggi Batam; Bapak Rektor UNRIKA; Seluruh Tim Pengarah penelitian dan Reviewer (Penyunting) Proposal dan Laporan penelitian; dan Jajaran kerja lingkup Lembaga Penelitian dan Pengabdian kepada Masyarakat (LPPM) UNRIKA. 


\section{REFERENSI}

Alfiyah, R., Nurlita A., Aunurohim dan Dewi, H., 2016. Studi Variasi Morfometrik Ikan Belanak (Mugil cephalus) Di Perairan Muara Aloo Di Sidoarjo dan Muara Wonorejo Surabaya. Program Studi Biologi, Laporan Praktikum Fakultas Matematika Ilmu Pengetahuan Alam. Institut Teknologi Sepuluh Nopember Surabaya. Surabaya.

Arifianti, D., 2006. Diktat Ichthyology. Universitas Brawijaya Press, Malang

Effendie, M. I., 2002. Biologi perikanan. Yayasan Pustaka Nusatama. Yogyakarta

Pasaribu, F., 2016. Keanekaragaman Ikan di Perairan Barat Pulau Batam yang Tertangkap Menggunakan Bubu dan Implementasinya dalam Buku Panduan Pengenalan Jenis Jenis Ikan Laut. (Skripsi) Prodi Pendidikan Biologi. FKIP Universitas Riau Kepulauan (UNRIKA) Batam. 87 pp.

Gazali, S., \& Firdaus, M., 2011. Analisis Potensi dan Aspek Morfometrik Reproduksi Ikan Puput (Ilisha elongata) yang Berasal dari Tangkapan Nelayan di Sekitar Perairan Kota Tarakan. Program Studi Manajemen Sumberdaaya Perairan. Fakultas Perikanan dan Ilmu Kelautan. Universitas Borneo, Tarakan.

Yuniar, I., 2017. Biologi Reproduksi Ikan. Hang Tuah University Press. Surabaya.

Muchlisin, Z.A., Musman, M., Siti-Azizah, M. N., 2010. Length-Weight Relationships and Condition Factors of Two Threatened Fishes, Rasbora tawarensis and Poropuntius tawarensis, Endemic to Lake Laut Tawar, Aceh Province, Indonesia. Journal of Applied Ichthyology, 26: 949-953.

Mulfizar, Muchlisin, Z. A., Dewiyanti, I., 2012. Hubungan Panjang Berat dan Faktor Kondisi Tiga Jenis Ikan Yang Tertangkap Di Perairan Kuala Gigieng, Aceh Besar, Provinsi Aceh. Depik, Vol. 1 (1): 1-9.

Muttaqin, Z., Dewiyanti, I., Aliza, D., 2016. Kajian Hubungan Panjang Berat Dan Faktor Kondisi Ikan Nila (Oreochromis niloticus) Dan Ikan Belanak (Mugil cephalus) Yang Tertangkap Di Sungai Matang Guru, Kecamatan Madat, Kabupaten Aceh Timur. Depik, Vol. 1(3): 397-403.

Okfan, A., Maskananfola, M.R., dan Djuwito, 2015. Studi Ekologi dan Aspek Biolgi Ikan Belanak (Mungil sp) di Perairan Muara Sungai Banger, Kota Pekalongan. Diponegoro Journal Of Maquares. Vol. 4(3): 156-163.

Ramadhani, A., Muchlisin, Z. A., Sarong, M.A., Batubara, A.S., 2017. Hubungan panjang berat dan faktor kondisi ikan kerapu Famili Serranidae yang tertangkap di Perairan Pulo Aceh Kabupaten Aceh Besar, Provinsi Aceh. Depik, 6(2): 112-1,

Redjeki, S., 2013. Komposisi dan Kelimpahan Ikan di Ekosistem Mangrove di Kedungmalang, Jepara. ILMU KELAUTAN. Volume 18(1):54-60 ISSN 0853-7291

Min, T. S., et. al., 1982. A Colour Guide to the Fishes of the South China Sea and the Andaman Sea. Primary Productin Departemen Singapore Singapore.

Usman, M. T., dan Affandi, R., 2017. Biologi Reproduksi Ikan. Intimedia, Malang.

Wahyudewantoro, G., dan Haryono, 2013. Hubungan Panjang Berat Dan Faktor Kondisi Ikan Belanak Liza subviridis Di Perairan Taman Nasional Ujung Kulon-Pandeglang, Banten. Bionatura-Jurnal Ilmu-ilmu Hayati dan Fisik, Vol. 15, No. 3: 175 - 178. 